\title{
PENGARUH PERMAINAN SIMAK-ULANG UCAP TERHADAP KEMAMPUAN MENYIMAK ANAK USIA 4-5 TAHUN DI RA AS-SYAFI'IYAH KOTA MEDAN
}

\author{
T.A 2018/2019
}

\author{
Oleh \\ Cynthia Fitri Kautsar*, Masganti Sitorus ", Ramadhan Lubis ${ }^{* * *}$ \\ *mahasiswa PIAUD, **dosen FITK UINSU Medan, *** dosen FITK UINSU Medan
}

\begin{abstract}
Abstrak
Penelitian ini bertujuan untuk mengetahui: 1) pengaruh permainan simak-ulang ucap terhadap kemampuan menyimak anak; 2) pengaruh metode bercerita terhadap kemampuan menyimak anak; 3) perbedaan pengaruh permainan simak-ulang ucap dengan metode bercerita terhadap kemampuan menyimak anak usia 4-5 tahun di RA As-Syafi'iyah.Penelitian ini adalah penelitian kuantitatif, jenis penelitian Quasi Eksperimen design. Jumlah populasi adalah 22 anak. Penarikan sample pada penelitian ini menggunakan teknik sample acak sederhana (simple random sampling).Hasil penelitian ini adalah: 1) Adanya pengaruh permainan simak-ulang ucap terhadap kemampuan menyimak anak, dibuktikan pada nilai rata-rata test 6,6 menjadi 15,$3 ; 2$ ) adanya pengaruh menggunakan metode bercerita terhadap kemampuan menyimak anak, dibuktikan pada nilai rata-rata test 5,0 menjadi 10,7 yang berjumlah 11 anak; 3) adanya perbedaan pengaruh antara permainan simak-ulang ucap dengan metode bercerita terhadap kemampuan menyimak anak usia 4-5 tahun di RA As-Syafi' 'iyah dilihat dari nilai $t_{\text {hitung }}=14,0988>t_{\text {tabel }}=2,086$.
\end{abstract}

Kata kunci: Kemampuan Menyimak, Permainan Simak-Ulang Ucap

\begin{abstract}
This reasearch is meant to find out: 1) the influence of the see-repeat speech game on children's listening abilities; 2) the influence of the method of storytelling on children's listening abilities; 3) the difference in the influence of the see-repeat speech game with the method of storytelling on children's listening abilities aged 4-5 years in RA As-Syafi'iyah. This research is a quantitative study, a type of Quasi Experiment design research. The population is 22 children. Sampling in this study uses a simple random sampling technique. The results of this study are: 1) The influence of the see-repeat speech game on children's listening abilities, as evidenced by the average test score of 6.6 to $15.3 ; 2$ ) the the influence of the method of storytelling on children's listening abilities, as evidenced by the average test score of 5.0 to 10.7, amounting to 11 children; 3) there is a difference in the influence between the see-repeat speech game with the method of storytelling on the ability to listen to children aged 4-5 years in RA As-Syafi'iyah seen from the tcount $=14.0988>$ ttable $=2.086$.
\end{abstract}

Keywords: Listening Ability, See-Repeat Speech Game

Corespondency Author:

* cynthiafitrikautsar@gmail.com

** masgantihaidapane@gmail.com

***ramadhanlubis@uinsu.ac.id 


\section{A. Pendahuluan}

Anak usia dini adalah mereka yang berusia antara 0-6 tahun. Pada usia ini perkembangan berpikir anak sangat pesat. Masa ini sering disebut dengan massa keemasan (Golden Age). Masa dimana segala potensi kemampuan anak dapat dikembangkan secara optimal, tentunya dengan bantuan orang - orang yang berada di sekitarnya, seperti keluarga dan guru. Salah satu kemampuan anak yang sedang berkembang disaat masa keemasan ini adalah kemampuan berbahasa. Penguasaan bahasa sangat erat kaitannya dengan kemampuan kognisi anak. Sistematika berbicara anak menggambarkan sisematikanya dalam berpikir.

Bromley (Dhieni, 2009) menyebutkan empat macam bentuk bahasa yaitu: menyimak, berbicara, membaca dan menulis. Bahasa ada yang bersifat reseptif (dimengerti, diterima) maupun ekspresif (dinyatakan). Keterampilan menyimak dan membaca merupakan keterampilan bahasa reseptif dalam keterampilan ini makna bahasa diperoleh dan diproses melalui simbol visual dan verbal. Menyimak dan membaca merupakan proses pemahaman. Sedangkan berbicara dan menulis merupakan keterampilan bahasa ekspresif yang melibatkan pemindahan arti melalui simbol visual dan verbal yang diproses dan diekspresikan anak. Berbicara dan menulis adalah proses penyusunan.

Maka dari itu kemampuan menyimak merupakan dasar yang harus dimiliki anak agar dapat mampu berbicara dengan baik. Karena menyimak adalah kegiatan yang disengaja dengan cara mendengarkan dengan seksama, penuh perhatian, pemahaman, apresiasi, agar dapat memahami makna komunikasi yang disampaikan secara lisan tersebut. Jika kemampuan menyimak anak sudah berkembang dengan baik, maka anak tersebut akan dapat memberikan respon yang positif dengan lawan berbicaranya.

Kemampuan menyimak tidak dapat dikuasai dengan sendirinya oleh anak. Akan tetapi, kemampuan menyimak tersebut akan diperoleh anak melalui proses pembelajaran atau upaya pengembangan kemampuan menyimak yang dilakukan orang tua atau guru. Dan proses pembelajaran atau upaya kemampuan menyimak anak harus dilakukan dengan menyenangkan dan menarik agar anak tidak mudah merasa bosan atau jenuh terhadap pembelajaran bahasa. Metode pembelajaran yang telah dilakukan dalam temuan terdahulu ialah metode Whole Language dan bercerita. Adapun metode lain yang dapat digunakan guru dalam proses pembelajaran atau upaya pengembangan kemampuan menyimak tersebut adalah permainan Simak-Ulang Ucap. Yang dilakukan untuk mengetes kemampuan memahami dan mengulang pesan yang diterima. Jenis menyimak yang dapat 
dikembangkan permainan simak ulang ucap ini ialah kemampuan menyimak informatif. Karena dalam permianan ini anak dituntut untuk mengidentifikasikan dan meningat pesanpesan pendek yang lucu, netral, dan pesan moral yang dikatakan guru atau temannya.

Dari hasil pengamatan yang dilakukan pada saat pra penelitian di RA As-Syafi'iyah Jalan Suka Tari No. 12 Kelurahan Suka Maju Kecamatan Medan Johor Kota Medan pembelajaran bahasa yang sering diterapkan yaitu bercerita, ceramah, dan penugasan. Sehingga pada saat pembelajaran bahasa untuk mengembangkan kemampuan menyimak dilakukan diperolehlah data bahwasanya terdapat $34.8 \%$ dari 22 siswa yang mampu menyampaikan dengan baik pesan yang didengarnya, dan $65.2 \%$ dari 22 siswa yang tidak mampu menyampaikan dengan baik pesan yang didengarnya. Hal tersebut terjadi karena anak tidak terbiasa dengan kegiatan pembelajaran tersebut, menyebabkan anak mudah bosan dan jenuh. Jika anak sudah merasa bosan maka anak susah untuk memusatkan perhatiannya pada apa yang didengarnya. Selain itu ketika anak diminta untuk menyampaikan pesan yang didengarnya dia tidak dapat menyampaiknnya dengan baik. Hal tersebut terjadi karena anak tidak mendengarkan dengan baik pesan yang disampaikan. Dan ada mudah lupa pada pesan yang didengarnya.

Diharapkan permainan simak-ulang ucap untuk mengembangkan kemampuan menyimak dapat membawa perubahan dalam belajar dan menarik bagi anak. Karena permainan simak-ulang ucap dapat mengasah kemampuan menyimak anak yaitu dalam mendengarkan dengan penuh perhatian, pemahaman, apresiasi, serta interpretasi untuk memperoleh informasi dan makna komunikasi yang disampaikan secara lisan.

Berdasarkan latar belakang yang dijelaskan di atas maka dapat disimpulkan rumusan masalah dalam penelitian ini yaitu:

1. Apakah permainan simak-ulang ucap di kelas eksperimen berpengaruh terhadap perkembangan kemampuan menyimak anak usia 4-5 Tahun di RA As-Syafi'iyah Jalan Suka Tari No. 12 Kelurahan Suka Maju Kecamatan Medan Johor Kota Medan ?

2. Apakah metode bercerita di kelas kontrol berpengaruh terhadap perkembangan kemampuan menyimak anak usia 4-5 Tahun di RA As-Syafi'iyah Jalan Suka Tari No. 12 Kelurahan Suka Maju Kecamatan Medan Johor Kota Medan?

3. Apakah ada perbedaan pengaruh permainan Simak-Ulang Ucap dengan metode bercerita terhadap kemampuan menyimak anak usia 4-5 tahun di RA As-Syafi'iyah Jalan Suka Tari No. 12 Kelurahan Suka Maju Kecamatan Medan Johor Kota Medan?. 


\section{B. Kajian Literatur}

\section{Permainan Simak Ulang Ucap}

Permainan dan bermain merupakan suatu kegiatan yang melekat pada dunia anak, karena sudah menjadi kodrat anak untuk bermain. Menurut Vygotsky (Khadijah, 2017) bermain mempunyai peran langsung terhadap perkembangan kognisi seorang anak, anak tidak mampu berpikir abstrak, karena bagi mereka makna dan objek berbaur menjadi satu.

Dalam metode pendidikan Rasulullah juga menggunakan metode bermain, di mana beliau senang bermain tebak-tebakan dengan sahabatnya. Imam Al Bukhari meriwayatkan dari Ibnu Umar, bahwa Rasulullah bersabda:

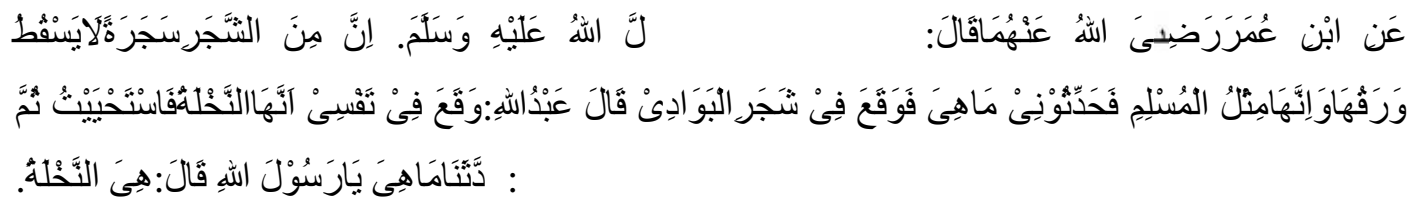

Artinya: Dari Ibnu Umar ra. Berkata: "Rasulullah saw. Bersabda: Sesungguhnya diantara pohon-pohon itu ada pohon yang daunnya tidak gugur, sesungguhnya itulah perumpamaan orang muslim, maka ceritakanlah kepada kami pohon apakah itu?" Orang-orang menduga pohon di padang pasir. Abdullah berkata: "Tergores dalam hatiku bahwa pohon itu adalah pohon kurma, namun saya malu”. Kemudian mereka berkata: Ceritakanlah pada kami pohon apakah itu wahai Rasulullah ?" Beliau bersabda: "Dia itu pohon kurma”. (Azzubaidi, 1986)

Dalam Al-Qur'an juga dijelaskan bahwa bersenang-senang dan bermain sebagaimana dilakukan oleh saudara Nabi Yusuf as. kepada dirinya dengan meminta izin kepada ayahya Nabi Ya'kub untuk memberi izin membawa Nabi Yusuf bermain-main, sebagaimana diabadikan dalam Surat Yusuf ayat 12 sebagai berikut:

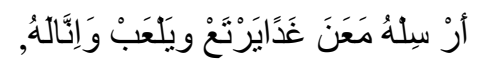

Artinya: "Biarkanlah dia pergi bersama Kami besok pagi, agar dia (dapat) bersenangsenang dan (dapat) bermain-main, dan sesungguhnya kami pasti menjaganya." (Q.S: Yusuf/ 12:12).

Dengan demikian bermainpun diperkenankan dalam ajaran Islam, karena diperlukan dalam kehidupan manusia untuk memperoleh kesenangan. Kegiatan bermain tidak terikat pada waktu tertentu kapan saja dikehendaki dapat dilakukan. Akan tetapi Islam juga memberikan petunjuk agar umat Islam tidak melalaikan diri taat kepada Allah atau menyia-nyiakan waktu akibat asyik bermain hanya untuk memperoleh kesenangan 
semata. Memperoleh kesenangan diperkenankan, tetapi melalaikan diri dari taat kepada Allah akibat terpengaruh memperoleh kesenangan sangat dicela dalam ajaran Islam.

Menurut Tadkirotun (Musfiroh, 2012) pengembangan kemampuan menyimak dapat dilakukan dengan berbagai cara, salah satunya dengan permainan simak-ulang ucap. Mukhtar (Mukhtar, 2006) menyatakan bahwa permainan simak-ulang ucap diperkenalkan dengan bunyi bahasa dan cara mengucapkannya. Guru mengucapkan kata-kata yang nantinya anak disuruh untuk mengikuti apa yang diucapkan oleh guru baik itu secara sendiri maupun kelompok. Guru dalam hal ini harus memberikan variasi dalam mengucapkan kata-kata yang diulang oleh siswa. Karena kalau kata-kata terlalu menoton akan mengakibatkan siswa cepat bosan dan terkadang siswa hanya membuka mulut tanpa bersuara. Pendekatan seperti ini cocok bagi pembelajaran bahasa pemula yaitu dengan mengajarkan pengucapan alphabet secara pas.

\section{Kemampuan Menyimak}

Menurut Sabarti yang dikutip Nurbiana mengemukakan bahwa menyimak adalah suatu proses yang mencakup kegiatan mendengarkan bunyi bahasa, mengidentifikasi, menginterpretasi, menilai, dan mereaksi atas makna yang terkandung di dalamnya. Karena kemampuan menyimak berkaitan erat dengan kemampuan berbahasa, khususnya berbicara. Anak yang berkembang kemampuan menyimaknya maka akan berpengaruh pada perkembangan kemampuan berbicaranya. Dalam Al-Qur'an juga dijelaskan bahwa setiap manusia harus memiliki kemampuan menyimak, seperti dijelaskan dalam Q.S Sad 38:29 :

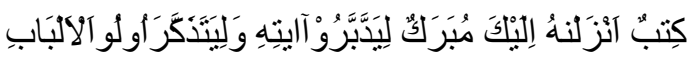

Artinya: “Kitab (Al-Qur'an) yang Kami turunkan kepadamu penuh berkah agar mereka menghayati ayat-ayatnya dan agar orang yang berakal sehat mendapat pelajarannya".(Q.S. Sad 38:29).

Maka dari itu kemampuan menyimak sangat dibutuhkan dalam memahami isi kandungan Al-Quran. Agar manusia megetahui hal-hal yang boleh dilakukan dan yang tidak boleh dilakukan dalam kehidupan ini, dan apa saja yang ada di langit dan di bumi yang telah Allah ciptakan. Setelah mereka memahaminya maka mereka mengapresiasikan dengan cara mengamalkannya, bersyukur kepada-Nya atas segala nikmat yang telah diberikan-Nya dan menyampaikannya kepada orang yang tidak mengetahui hal itu. 


\section{Metode Penelitian}

Penelitian ini dilaksanakan di RA As-Syafi'iyah Jalan Suka Tari No. 12 Kelurahan Suka Maju Kecamatan Medan Johor . Metode penelitian yang digunakan peneliti adalah metode eksperimen (quasi eksperimen design). Quasi Eksperimental Desain mempunyai dua kelompok yaitu kelompok kontrol dan kelompok eksperimen, tetapi tidak dapat berfungsi sepenuhnya mengontrol variabel-variabel luar yang mempengaruhi pelaksanaan eksperimen. Populasi penelitian adalah seluruh siswa di RA As-Syafi'iyah. Penarikan sample pada penelitian ini menggunakan teknik sample acak sederhana (simple random sampling). Pengambilan sampel dilakukan dengan undian, maka setiap anggota terlebih dahulu diberi kode dan dituliskan pada sebuah kertas kecil yang di gulung, penulisannya berupa angka dan huruf A1-A11 untuk kelas Eksperimen sedangkan B1-B11 untuk kelas Kontrol. Selanjutnya kode-kode tersebut diambil secara acak. Kode sampel yang terambil dijadikan sampel penelitian. Adapun Kegiatan di kelas eksperimen yaitu permainan simakulang ucap dan kegiatan di kelas kontrol yaitu menggunakan metode bercerita.

\section{Hasil Temuan dan Pembahasan}

\section{Hasil Observasi Kemampuan Menyimak}

Hasil observasi kemampuan menyimak anak di kelas eksperimen dengan menggunakan permainan simak-ulang ucap pada anak di RA As-Syafi'iyah, sebagai berikut:

Tabel 1 Nilai hasil observasi kemampuan menyimak anak dengan menggunakan permainan simak-ulang ucap

\begin{tabular}{|c|c|c|}
\hline No. & $\mathbf{Y}_{\mathbf{1}}$ & $\mathbf{X}_{\mathbf{1}}$ \\
\hline A01. & 4 & 14 \\
\hline A02. & 5 & 14 \\
\hline A03. & 5 & 15 \\
\hline A04. & 6 & 15 \\
\hline A05. & 7 & 15 \\
\hline A06. & 7 & 16 \\
\hline A07. & 7 & 16 \\
\hline A08. & 8 & 16 \\
\hline A09. & 8 & 16 \\
\hline
\end{tabular}




\begin{tabular}{|c|c|c|}
\hline A10. & 8 & 16 \\
\hline A11. & 8 & 16 \\
\hline Jumlah & $\mathbf{7 3}$ & $\mathbf{1 6 9}$ \\
\hline Rata-rata & $\mathbf{6 , 6 3 6 3}$ & $\mathbf{1 5 , 3 6 3 6}$ \\
\hline Modus & $\mathbf{8}$ & $\mathbf{1 6}$ \\
\hline Median & $\mathbf{7}$ & $\mathbf{1 6}$ \\
\hline
\end{tabular}

Dari tabel di atas, diketahui bahwa hasil observasi kegiatan dengan permainan simak-ulang ucap pre test di kelas eksperimen dengan memperoleh nilai rata-rata 6,6363 dengan nilai terendah 4 dan nilai tertinggi 8 , modusnya 8 dan mediannya adalah 7 , dan kegiatan dengan metode bercerita post test di kelas eksperimen dengan memperoleh nilai rata-rata dengan nilai 15,3636 terendah 14 dan nilai tertinggi 16 , modusnya 16 dan mediannya adalah 16. Hasil observasi kemampuan menyimak anak di kelas kontrol dengan menggunakan metode bercerita pada anak di RA As-Syafi'iyah sebagai berikut:

Tabel 2 Nilai hasil observasi kemampuan menyimak anak dengan menggunakan metode bercerita

\begin{tabular}{|c|c|c|}
\hline No. & $\mathbf{Y}_{\mathbf{2}}$ & $\mathbf{X}_{\mathbf{2}}$ \\
\hline B01. & 4 & 10 \\
\hline B02. & 4 & 10 \\
\hline B03. & 4 & 10 \\
\hline B04. & 4 & 10 \\
\hline B05. & 4 & 10 \\
\hline B06. & 5 & 11 \\
\hline B07. & 5 & 11 \\
\hline B08. & 6 & 11 \\
\hline B09 & 6 & 11 \\
\hline B10 & 7 & 12 \\
\hline B11 & 7 & 12 \\
\hline Jumlah & $\mathbf{5 6}$ & $\mathbf{1 1 8}$ \\
\hline Rata-rata & $\mathbf{5 , 0 9 0 9}$ & $\mathbf{1 0 , 7 2 7 2}$ \\
\hline Modus & $\mathbf{4}$ & $\mathbf{1 0}$ \\
\hline Median & $\mathbf{5}$ & $\mathbf{1 1}$ \\
\hline
\end{tabular}


Dari tabel di atas, diketahui bahwa hasil observasi dengan metode bercerita pada anak di kelas kontrol pre test diperoleh dengan nilai rata-rata 5,0909 dengan nilai tertinggi 7 dan nilai terendah 3, modusnya adalah 6 dan mediannya adalah 5, dan kegiatan dengan metode bercerita pada anak kelas kontrol post test diperoleh dengan nilai rata-rata 10,7272 dengan nilai tertinggi 12 dan nilai terendah 10, modusnya adalah 10 dan mediannya adalah 11.Setelah diketahui kemampuan menyimak awal anak, kemudian kelas eksperimen dan kelas kontrol diberikan perlakuan. Untuk kelas eksperimen diterapkan dengan permainan simak-ulang ucap, sedangkan di kelas kontrol diterapkan dengan metode bercerita. Pada akhir pertemuan, anak kembali diberikan post test. Tujuan diberikannya post test adalah untuk mengetahui kemampuan menyimak anak dari satu kelas yang sudah dibagi menjadi 2 kelompok setelah dilakukan kegiatan dengan permainan simak-ulang ucap pada kelas ekperimen dan menggunakan metode bercerita pada kelas kontrol.

Berikut adalah ringkasan hasil pre test kelas eksperimen dan kelas kontrol yang satu kelas dibagi menjadi dua kelompok pada tabel berikut

Tabel 3 Hasil pre test kelas eksperimen dan kelas kontrol yang satu kelas dibagi menjadi dua kelompok.

\begin{tabular}{|c|l|c|c|}
\hline No. & \multicolumn{1}{|c|}{ Statistik } & Kelas Eksperimen & Kelas Kontrol \\
\hline 1. & N & 11 & 11 \\
\hline 2. & Jumlah Skor & 73 & 56 \\
\hline 3. & Rata-Rata & 6,6363 & 5,0909 \\
\hline 4. & S.Baku & 1,4317 & 1,2206 \\
\hline 5. & Varians & 2,0546 & 1,491 \\
\hline 6. & Maksimum & 8 & 7 \\
\hline 7. & Minimum & 4 & 4 \\
\hline
\end{tabular}

Dari informasi yang disajikan dalam tabel di atas dapat dilihat $\mathrm{N}$ (jumlah anak) sama-sama berjumlah 11, dengan jumlah skor di kelas eksperimen 73 dan kelas kontrol 56, dengan perbedaan skor yang diperoleh adalah 17. Nilai rata-rata di kelas eksperimen 6,6363 dan di kelas kontrol 5,0909. Simpangan baku di kelas eksperimen 1,4317 dan di kelas kontrol 1,2206. Varian di kelas ekperimen 2,0546 dan di kelas kontrol 1,491. Nilai yang diperoleh terbanyak yang diperoleh di kelas ekperimen adalah 8 sedangkan di kelas kontrol 7. Dan nilai terendah yang diperoleh di kelas eksperimen adalah 4 dan di kelas kontrol juga 4. 
Berikut disajikan diagram perbedaan perhitungan statistika pre test pada kelas eksperimen dan kelas kontrol:

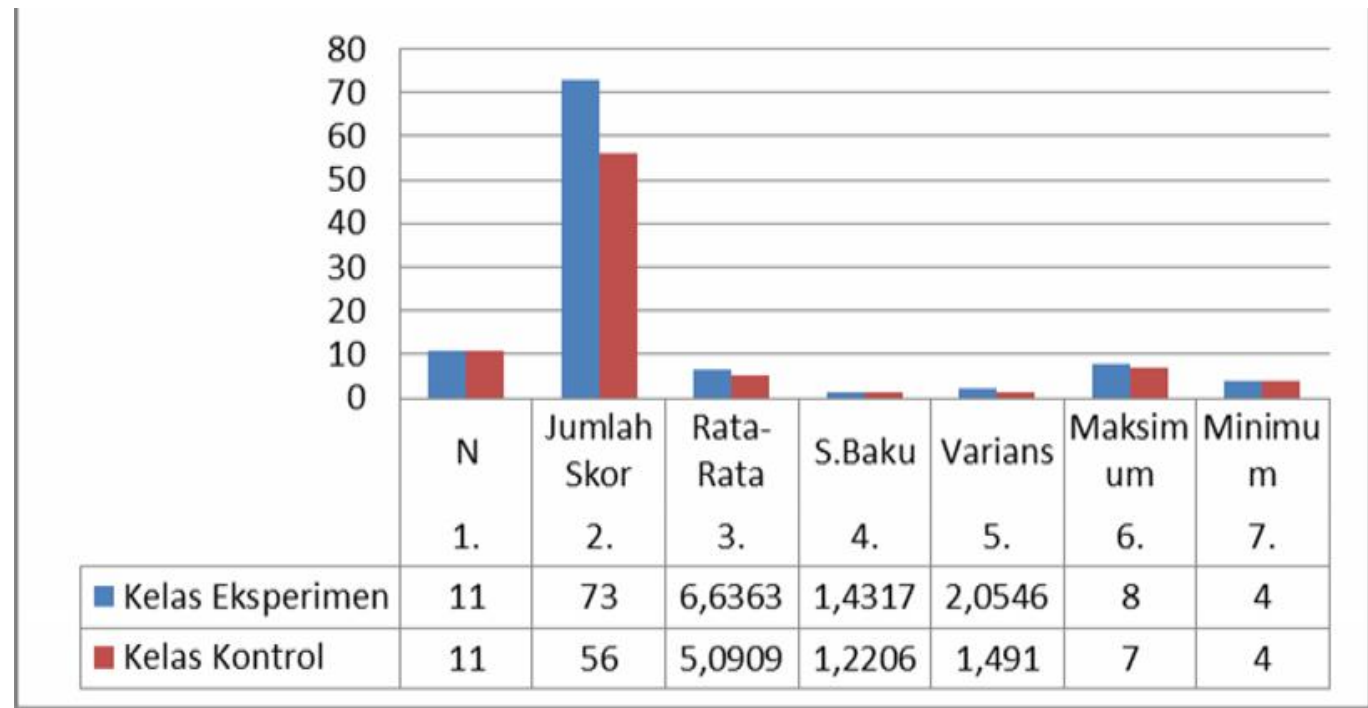

Gambar 1 Diagram Data Pre Test Kelas Eksperimen dan Kelas Kontrol

Dapat disimpulkan dari tabel dan diagram di atas bahwasanya terdapat perbedaan antara kelas eksperimen dan kelas kontrol dalam hal perhitungan statistik pre test sebelum diberikan perlakuan yang berbeda.

Tabel 4 Hasil post test kelas eksperimen dan kelas kontrol yang satu kelas dibagi menjadi dua kelompok.

\begin{tabular}{|c|l|c|c|}
\hline No. & \multicolumn{1}{|c|}{ Statistik } & Kelas Eksperimen & Kelas Kontrol \\
\hline 1. & $\mathrm{~N}$ & 11 & 11 \\
\hline 2. & Jumlah Skor & 169 & 118 \\
\hline 3. & Rata-Rata & 15,3636 & 10,7272 \\
\hline 4. & S.Baku & 0,8062 & 0,7810 \\
\hline 5. & Varians & 0,655 & 0,6182 \\
\hline 6. & Maksimum & 16 & 13 \\
\hline 7. & Minimum & 14 & 10 \\
\hline
\end{tabular}

Dari informasi yang disajikan dalam tabel di atas dapat dilihat $\mathrm{N}$ (jumlah anak) sama-sama berjumlah 11, dengan jumlah skor di kelas eksperimen 169 dan kelas kontrol 118, dengan perbedaan skor yang diperoleh adalah 51. Nilai rata-rata di kelas eksperimen 15,3636 dan di kelas kontrol 10,7272. Simpangan baku di kelas eksperimen 0,8062 dan di kelas kontrol 0,7810. Varian di kelas ekperimen 0,655 dan di kelas kontrol 0,6182. Nilai 
yang diperoleh terbanyak yang diperoleh di kelas ekperimen adalah 16 sedangkan di kelas kontrol adalah 13. Dan nilai terendah yang diperoleh di kelas eksperimen adalah 14 dan di kelas kontrol adalah 10.

Berikut disajikan diagram perbedaan perhitungan statistika post test pada kelas eksperimen dan kelas kontrol:

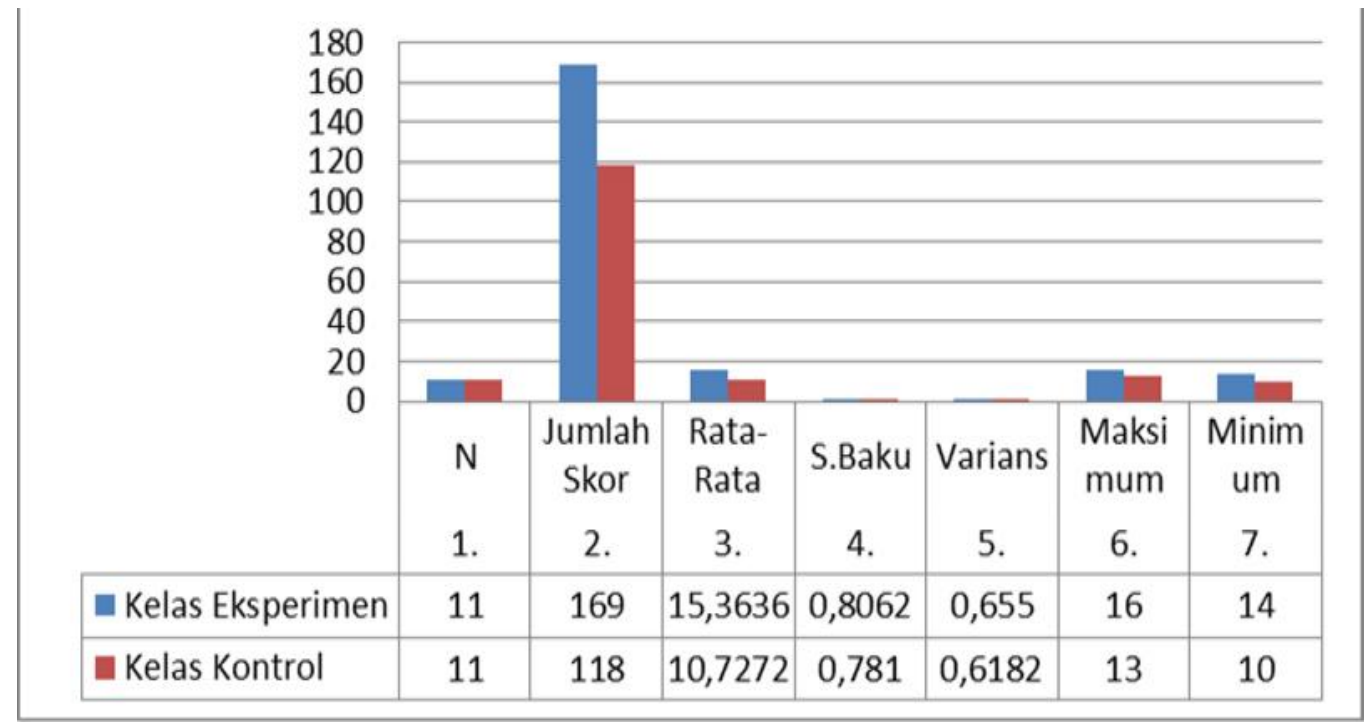

Gambar 2 Diagram Data Post Test Kelas Eksperimen dan Kelas Kontrol

Dapat disimpulkan dari tabel dan diagram di atas bahwasanya terdapat perbedaan antara kelas eksperimen dan kelas kontrol dalam hal perhitungan statistik post test setelah diberikan perlakuan yang berbeda.

2. Hasil Uji Hipotesis

\section{a) Uji Normalitas Data}

Untuk menguji normalitas data digunakan uji Liliefors yang bertujuan untuk mengetahui apakah penyebaran data hasil penelitian memiliki sebaran data yang berdistribusi normal atau tidak. Sampel berdistribusi normal jika dipenuhi $L_{0}<L_{\text {tabel }}$ pada taraf signifikan $\alpha=0,05$.

Uji normalitas data pre test kemampuan menyimak anak pada kelas eksperimen diperoleh $\mathrm{L}_{0}(0,1711)<\mathrm{L}_{\text {tabel }}(0,249)$ dan data pre test kelas kontrol diperoleh $\mathrm{L}_{0}(0,2678)$ $>\mathrm{L}_{\text {tabel }}(0,249)$. Dari data post test kemampuan menyimak anak pada kelas eksperimen diperoleh $\mathrm{L}_{0}(0,2119)<\mathrm{L}_{\text {tabel }}(0,249)$ dan data post test pada kelas kontrol diperoleh $\mathrm{L}_{0}$ $(0,2757)>\mathrm{L}_{\text {tabel }}(0,249)$. Dengan demikian dapat disimpulkan bahwa distribusi data pre test perkembangan kemampuan menyimak anak dengan menggunakan permainan simak- 
ulang ucap di kelas eksperimen dan metode bercerita di kelas kontrol berdistribusi normal, sedangkan distribusi data post test perkembangan kemampuan menyimak anak dengan menggunakan permainan simak-ulang ucap di kelas eksperimen dan metode bercerita di kelas control tidak berdistribusi normal.

Secara ringkas perhitungan data hasil penelitian diperlihatkan pada tabel berikut:

Tabel 5 Ringkasan Hasil Uji Normalitas Data Kemampuan Menyimak Anak

\begin{tabular}{|c|c|c|c|c|c|c|}
\hline \multirow{2}{*}{ Kelas } & \multicolumn{3}{|c|}{ Pre Test } & \multicolumn{3}{c|}{ Post Test } \\
\cline { 2 - 7 } & $\mathbf{L}_{\mathbf{0}}$ & $\mathbf{L}_{\text {tabel }}$ & Keterangan & $\mathbf{L}_{\mathbf{0}}$ & $\mathbf{L}_{\text {tabel }}$ & Keterangan \\
\hline Eksperimen & 0,1711 & 0,249 & Normal & 0,2119 & 0,249 & Normal \\
\hline Kontrol & 0,2678 & 0,249 & Normal & 0,2757 & 0,249 & Normal \\
\hline
\end{tabular}

b) Uji Homogenitas

Pengujian homogenitas data untuk mengetahui apakah sampel yang digunakan dalam penelitian berasal dari populasi yang homogen atau tidak. Untuk pengujian homogenitas digunakan uji kesamaan kedua varians yaitu uji $\mathrm{F}$. Jika $\mathrm{F}_{\text {hitung }} \mathrm{F}_{\text {tabel }}$ maka $\mathrm{H}_{0}$ ditolak dan jika $\mathrm{F}_{\text {hitung }}<\mathrm{F}_{\text {tabel }}$ maka $\mathrm{H}_{0}$ diterima. Dengan derajat kebebasan pembilang $=\left(\mathrm{n}_{1}-1\right)$ dan derajat kebebasan penyebut $=\left(\mathrm{n}_{2}-1\right)$ dengan taraf nyata $\alpha=0,05$. Ringkasan hasil perhitungan uji homogenitas kemampuan menyimak anak disajikan pada tabel berikut:

Tabel 6 Data Hasil Uji Homogenitas Kemampuan Menyimak Anak

\begin{tabular}{|c|c|c|c|c|c|}
\hline Data & Varians Terbesar & Varians Terkecil & $\mathbf{F}_{\text {hitung }}$ & $\mathbf{F}_{\text {tabel }}$ & Keterangan \\
\hline Pre Test & 1,4317 & 1,2206 & 1,1729 & 2,978 & Homogen \\
\hline Data & Varians Terbesar & Varian Terkecil & $\mathrm{F}_{\text {hitung }}$ & $\mathrm{F}_{\text {tabel }}$ & Keterangan \\
\hline Post Test & 1,0344 & 0,8062 & 1,2830 & 2,978 & Homogen \\
\hline
\end{tabular}

\section{c) Pengujian Hipotesis}

Setelah diketahui bahwa kelas eksperimen dan kelas kontrol berdistribusi normal dan homogen, selanjutnya dilakukan pengujian hipotesis. Pengujian hipotesis dalam penelitian ini menggunakan uji t.

Pengujian hipotesis dilakukan uji satu pihak sehingga kriteria untuk menerima atau menolak $\mathrm{H}_{0}$ ialah jika $\mathrm{t}_{\text {hitung }}>$ pada taraf nyata $\alpha=0,05 \mathrm{H}_{\mathrm{a}}$ diterima dan $\mathrm{H}_{0}$ ditolak. Diperoleh nilai $\mathrm{t}_{\text {hitung }}=24,4736$ dengan taraf $\alpha=0,05$ didapat tabel t pada dk 9 diperoleh nilai $t_{\text {tabel }}=2,262$. Karena $t_{\text {hitung }}>t_{\text {tabel }}$, maka $\mathrm{H}_{0}$ ditolak dan $\mathrm{H}_{\mathrm{a}}$ diterima. Kesimpulannya ada pengaruh permainan simak-ulang ucap terhadap kemampuan menyimak anak usia 4- 
5tahun di di RA As-Syafi'iyah JL. Suka Tari No. 12 Kelurahan Suka Maju Kecamatan Medan Johor.

Diperoleh nilai $\mathrm{t}_{\text {hitung }}=12,8741$ dengan taraf $\alpha=0,05$ didapat tabel $\mathrm{t}$ pada $\mathrm{dk} 9$ diperoleh nilai $t_{\text {tabel }}=2$ 2,262. Karena $t_{\text {hitung }}>t_{\text {tabel }}$, maka $\mathrm{H}_{0}$ ditolak dan $\mathrm{H}_{\mathrm{a}}$ diterima. Kesimpulannya ada pengaruh metode bercerita terhadap kemampuan menyimak anak usia 4-5tahun di di RA As-Syafi'iyah JL. Suka Tari No. 12 Kelurahan Suka Maju Kecamatan Medan Johor.

Dari hasil analisis data membuktikan bahwa terdapat perbedaan yang signifikan terhadap kemampuan menyimak anak yang mengikuti pembelajaran dengan permainan simak-ulang ucap dengan anak yang mengikuti pembelajaran dengan metode bercerita. Hal ini ditunjukkan dari hasil analisis data dengan menggunakan uji-t, diketahui nilai kelas eksperimen Diperoleh nilai $t_{\text {hitung }}=24,4736$ dengan taraf $\alpha=0,05$ didapat tabel t pada dk 9 diperoleh nilai $t_{\text {tabel }}=2,262$. Hasil perhitungan tersebut menunjukkan bahwa $t_{\text {hitung }}>t_{\text {tabel, }}$, sehingga hasil penelitian adalah signifikan.

Sedangkan nilai dikelas kontrol di peroleh nilai $t_{\text {hitung }}=12,8741 \quad$ dengan taraf $\alpha$ $=0,05$ didapat tabel $\mathrm{t}$ pada $\mathrm{dk} 9$ diperoleh nilai $\mathrm{t}_{\text {tabel }}=2,262$. Hasil perhitungan tersebut menunjukkan bahwa $t_{\text {hitung }}>t_{\text {tabel, }}$ sehingga hasil penelitian adalah signifikan. Hal ini berarti, terdapat perbedaan signifikan, berdasarkan deskripsi data hasil penelitian, kelompok anak yang belajar dengan permainan simak-ulang ucap memiliki kemampuan menyimak lebih tinggi dibandingkan anak yang belajar melalui metode bercerita anak usia 4-5tahun di RA As-Syafi'iyah JL. Suka Tari No. 12 Kelurahan Suka Maju Kecamatan Medan Johor. Berikut disajikan dalam tabel hasil perhitungan uji hipotesis:

Tabel 7 Data Hasil Perhitungan Uji Hipotesis

\begin{tabular}{|c|c|c|c|c|}
\hline $\mathbf{N o}$ & Uji Hipotesis & $\mathbf{T}_{\text {hitung }}$ & $\mathbf{T}_{\text {tabel }}$ & Kesimpulan \\
\hline $\mathbf{1}$ & Kelas eksperimen & 24,4736 & 2,262 & $\mathrm{~T}_{\text {hitung }}>\mathrm{T}_{\text {tabel }}$ \\
\hline $\mathbf{2}$ & Kelas control & 12,8741 & 2,262 & $\mathrm{~T}_{\text {hitung }}>\mathrm{T}_{\text {tabel }}$ \\
\hline
\end{tabular}

Sedangkan hasil analisis data dengan menggunakan uji-t, diketahui nilai post test dari kelas kontrol dan kelas eksperimen nilai $t_{\text {hitung }}=13,6339$ dengan taraf $\alpha=0,05$ didapat tabel $\mathrm{t}$ pada $\mathrm{dk} 20$ diperoleh nilai $\mathrm{t}_{\text {tabel }}=2,086$. Hasil perhitungan tersebut menunjukkan bahwa $t_{\text {hitung }}>t_{t a b e l}$, sehingga hasil penelitian adalah signifikan. Berikut disajikan dalam tabel hasil perhitungan uji hipotesis nilai posttest kelas eksperimen dan kelas kontrol: 
Tabel 8 Data Hasil Perhitungan Uji Hipotesis Nilai Posttes Kelas Eksperimen dan Kelas Kontrol

\begin{tabular}{|c|c|c|c|c|c|}
\hline \multicolumn{2}{|c|}{ Rata-Rata Nilai Post Test } & \multirow{2}{*}{ DK } & $\mathbf{T}_{\text {hitung }}$ & $\mathbf{T}_{\text {tabel }}$ & \multirow{2}{*}{ Kesimpulan } \\
\cline { 1 - 2 } Kelas Eksperimen & Kelas Kontrol & & & & \\
\hline 15,3636 & 10,7272 & 20 & 13,6339 & 2,086 & $\mathrm{~T}_{\text {hitung }}>\mathrm{T}_{\text {tabel }}$ \\
\hline
\end{tabular}

Tinjauan ini didasarkan pada rata-rata skor hasil kemampuan menyimak anak. Ratarata nilai posttest anak yang belajar melalui permainan simak - ulang ucap adalah 15,3636 yang berada pada kategori tinggi dan nilai rata-rata posttest kemampuan menyimak anak yang belajar melalui metode bercerita adalah 10,7272 yang berada pada kategori rendah.

\section{E. Kesimpulan dan Saran}

Berdasarkan hasil penelitian dan pembahasan dapat diperoleh beberapa kesimpulan, yaitu sebagai berikut: (1) Adanya pengaruh permainan simak-ulang ucap di kelas eksperimen terhadap kemampuan menyimak anak usia 4-5 tahun di RA As-Syafi'iyah. Hal ini dibuktikan pada kelas eksperimen dengan nilai rata-rata pre test $(6,6363)$ dan nilai ratarata post test $(15,3636)$ yang berjumlah 11 anak dengan nilai $t_{\text {hitung }}=24,4736$ dengan taraf $\alpha=0,05$ didapat tabel $\mathrm{t}$ pada $\mathrm{dk} 9$ diperoleh nilai $\mathrm{t}_{\text {tabel }}=2,262$. Karena $\mathrm{t}_{\text {hitung }}>\mathrm{t}_{\text {tabel }}$, maka $\mathrm{H}_{0}$ ditolak dan $\mathrm{H}_{\mathrm{a}}$ diterima; (2) Adanya pengaruh dengan menggunakan metode bercerita di kelas kontrol terhadap kemampuan menyimak anak usia 4-5 tahun di RA As-Syafi'iyah. Hal ini dibuktikan pada kelas kontrol dengan nilai rata-rata pre test $(5,0909)$ dan post test $(10,7272)$ yang berjumlah 11 anak, dengan nilai $t_{\text {hitung }}=12,8741$ dengan taraf $\alpha=0,05$ didapat tabel $\mathrm{t}$ pada $\mathrm{dk} 9$ diperoleh nilai $\mathrm{t}_{\text {tabel }}=2$ 2,262. Karena $\mathrm{t}_{\text {hitung }}>\mathrm{t}_{\text {tabel }}$, maka $\mathrm{H}_{\mathrm{a}}$ diterima dan $\mathrm{H}_{0}$ ditolak; dan (3) Berdasarkan penelitian dan hasil analisis data yang telah dilakukan maka dapat disimpulkan bahwa terdapat perbedaan pengaruh antara permainan simak-ulang ucap dengan metode bercerita terhadap kemampuan menyimak anak usia 4-5 tahun di RA As-Syafi'iyah JL. Suka Tari No. 12 Kelurahan Suka Maju Kecamatan Medan Johor. Hal ini dilihat dari hasil analisis data dengan menggunakan uji-t, diketahui nilai post test dari kelas kontrol dan kelas eksperimen nilai $t_{\text {hitung }}=13,6339$ dengan taraf $\alpha=$ 0,05 didapat tabel $\mathrm{t}$ pada $\mathrm{dk} 20$ diperoleh nilai $\mathrm{t}_{\text {tabel }}=2,086$. Hasil perhitungan tersebut menunjukkan bahwa $t_{\text {hitung }}>t_{\text {tabel, }}$ sehingga hasil penelitian adalah signifikan.

Berdasarkan kesimpulan dari hasil penelitian, maka peneliti mengajukan beberapa saran yang ditujukan kepada berbagai pihak yang berkepentingan dengan hasil penelitian 
ini, diantaranya: (1) Kepada kepala sekolah disarankan agar dapat menerapkan model pembelajaran saintifik di sekolah, mampu menyediakan fasilitas-faslitas yang mendukung saat menerapkan permainan simak-ulang ucap agar perkembangan kemampuan menyimak anak semakin meningkat; (2) Bagi guru disarankan dalam satu minggu harus ada menerapkan permainan simak-ulang ucap kepada anak untuk mengembangkan dan meningkatkan kemampuan menyimak; (3) Bagi orangtua disarankan untuk melatih anak kembali di rumah dalam menerapkan langkah-langkah permainan simak-ulang ucap setelah diajarkan di sekolah dengan cara mentimulus anak untuk mengamati lingkungan disekitar rumah; dan (4) Kepada peneliti selanjutnya yang ingin melakukan penelitian yang sama, disarankan untuk mengembangkan penelitian ini dengan mempersiapkan sajian model kegiatan-kegiatan lain dan dapat mengoptimalkan waktu, guna meningkatkan kemampuan menyimak anak. Hasil dan perangkat penelitian ini dapat dijadikan pertimbangan untuk menggunakan permainan simak-ulang ucap ataupun model kegiatankegiatan lainnya.

\section{Daftar Pustaka}

Azzubaidi, Z. A. (1986). Terjemahan Hadist Shohih Bukhari. Semarang: Toha Putra.

Dhieni, N. (2009). Metode Pengembangan Bahasa. Jakarta : Universitas Terbuka.

Khadijah. (2017). Bermain dan Permainan Anak Usia Dini. Medan : Perdana Publishing. Mukhtar. (2006). Menyimak. Pekanbaru: Cendikia Insani.

Musfiroh, T. (2012). Pengembangan Kecerdasan Majemuk. Jakarta: Universitas Terbuka. RI, D. A. (2014). Yasmin Al-Qur'an Terjemahan dan Tajwid. Jakarta: Sigma. 